DOI: $\square$ https://doi.org/10.15407/techned2020.04.041

\title{
OPTIMIZATION OF MAGNETIZATION AND DEMAGNETIZATION PROCESSES OF THE VECTOR CONTROLLED ASYNCHRONOUS MOTOR
}

Journal

Publisher

ISSN

Issue

Pages
Tekhnichna elektrodynamika

Institute of Electrodynamics National Academy of Science of Ukraine 1607-7970 (print), 2218-1903 (online)

No 4, 2020 (July/August)

$41-45$

\section{Authors}

O.I. Tolochko*, D.V. Kaluhin**

National Technical University of Ukraine "Igor Sikorsky Kyiv Polytechnic Institute",

Peremohy ave., 37, 03056, Kyiv, Ukraine,

e-mail: tolochko.ola@gmail.com

* ORCID ID : https://orcid.org/0000-0002-6871-0653

** ORCID ID : https://orcid.org/0000-0003-1293-4479

\begin{abstract}
It was found the optimal time constants of the exponential laws of magnetization and demagnetization for induction motor with vector-control. It allows minimizing heat losses from field components of the stator and rotor currents. In addition, formulas for calculating these losses are found. Comparison of processes with standard and optimal control laws according to exponential and linear laws by the method of mathematical modeling is performed. References 9 , figures 2, table 1.
\end{abstract}

Key words: induction motor, demagnetization, magnetization, optimization.

Received: 28.02.2020

Accepted: 17.04 .2020

Published: 26.06.2020 


\section{References}

1. Diachenko G.G., Aziukovskyi O.O. Review of methods for energy-efficiency improvement in induction machines. Naukovyi Visnyk Natsionalnoho Hirnychoho Universytetu. 2020. No 1. Pp. 80-88.

DOI: http

s://doi.org/10.33271/nvngu/2020-1/080

2. Borisevich A. Numerical method for power losses minimization of vector-controlled induction motor. International Journal of Power Electronics and Drive System(IJPEDS). 2015. Vol. 6. No

3. Pp. 486-497.

DOI: https:

//doi.org/10.11591/ijpeds.v6.i3.pp486-497

3. Seena T., Rinu A.K. Efficiency optimization with improved transient performance of indirect vector controlled induction motor drive. International Journal of advanced research in electrical, electronics and instrumentation engineering

. 2013. Vol.

2. Pp. 374-385.

4. Blanusa B.D., Dokic B.L. Vukosavic S.N. Efficiency optimized control of high performance induction motor drive. Electronics. 2009. Vol. 13, No 2. Pp. 8-13.

5. Braslavsky I.A., Kostyliev A.V., Stepaniuk D.P. Optimization of Starting Process of the Frequency Controlled Induction Motor. 13th International Power Electronics and Motion Control Conference

Pp. 1050-1053. (EPE-PEMC-2008). Poznan, Poland, 2008.

/EPEPEMC.2008.4635406

6. Tolochko O.I., Rozkaryaka P.I., Chekavskii G.S., Kuzhel A.K. Control of induction motor magnetization and demagnetization processes in field-oriented control systems.

Electromechanical and energy saving systems. Quarterly scientific and industrial journal. 2011. Vol. 3(15). Pp. 79-82 (Rus).

7. Volkov V.A. Optimization of magnetization and demagnetization modes in frequency-controlled induction motor. Electrotechinca and energetica. Scientific proceedings of DonNTU . 2013. Vol. 2.

Pp. 59-66 (Rus).

8. Tolochko O., Sopiha M. Heat loss minimization field control of motionless induction motors in pause of intermittent duty. IEEE First Ukraine Conference on Electrical and Computer Engineering (UKRCON). Kyiv, Ukraine, 2017. Pp. 442-447. DOI: htt ps://doi.org/10.1109/UKRCON.2017.8100525

9. Volkov V.A. Optimization of magnetization and demagnetization times of a stopped frequency-controlled induction motor. Elekrotekhnika i elektrichestvo. 2018. No. 4. Pp. 17-29 (Rus). DOI:

https://doi.org/ $\underline{10.15588 / 1607-6761-2018-4-2}$ 
$\underline{\text { PDF }}$

@ $\Theta \Theta \odot$

This work is licensed under a Creative Commons Attribution-NonCommercial-NoDerivatives 4.0 International License 